\title{
Calcium and cell death signaling in neurodegeneration and aging
}

\author{
SORAYA SMAILI, HANAKO HIRATA, RODRIGO URESHINO, PRISCILA T. MONTEFORTE, \\ ANA P. MORALES, MARI L. MULER, JULIANA TERASHIMA, KAREN OSEKI, \\ TATIANA R. ROSENSTOCK, GUIOMAR S. LOPES and CLAUDIA BINCOLETTO \\ Departamento de Farmacologia, Universidade Federal de São Paulo, Escola Paulista de Medicina \\ Rua Três de Maio, 100, 04044-020 São Paulo, SP, Brasil \\ Manuscript received on July 21, 2008; accepted for publication on February 16, 2009; \\ presented by LUIZ R. TRAVASSOS
}

\begin{abstract}
Transient increase in cytosolic $\left(\mathrm{Ca}_{\mathrm{c}}^{2+}\right)$ and mitochondrial $\mathrm{Ca}^{2+}\left(\mathrm{Ca}_{\mathrm{m}}^{2+}\right)$ are essential elements in the control of many physiological processes. However, sustained increases in $\mathrm{Ca}_{\mathrm{c}}^{2+}$ and $\mathrm{Ca}_{\mathrm{m}}^{2+}$ may contribute to oxidative stress and cell death. Several events are related to the increase in $\mathrm{Ca}_{\mathrm{m}}^{2+}$, including regulation and activation of a number of $\mathrm{Ca}^{2+}$ dependent enzymes, such as phospholipases, proteases and nucleases. Mitochondria and endoplasmic reticulum (ER) play pivotal roles in the maintenance of intracellular $\mathrm{Ca}^{2+}$ homeostasis and regulation of cell death. Several lines of evidence have shown that, in the presence of some apoptotic stimuli, the activation of mitochondrial processes may lead to the release of cytochrome $\mathrm{c}$ followed by the activation of caspases, nuclear fragmentation and apoptotic cell death. The aim of this review was to show how changes in calcium signaling can be related to the apoptotic cell death induction. Calcium homeostasis was also shown to be an important mechanism involved in neurodegenerative and aging processes.
\end{abstract}

Key words: calcium, apoptosis, Bax, mitochondria, endoplasmic reticulum, neurodegeneration and aging.

\section{CELL DEATH MECHANISMS}

Cell death is one of the primordial events in cellular life and there are several mechanisms through which cells achieve death. Both necrotic and apoptotic cell death are characterized by biochemical and morphological differences. Necrosis is usually involved in some death stimuli related to pathologies and accidental events which are not well regulated. There are certain features that characterize the two types of cell death, one of them related to the ATP levels. When the levels of ATP are low, cells undergo necrosis instead of apoptosis. Frequently, several features related to necrosis and apoptosis may occur simultaneously in the presence of cell death stimuli. This was described as necrapoptosis which may occur espe-

In commemoration of the $75^{\text {th }}$ anniversary of

Escola Paulista de Medicina / Universidade Federal de São Paulo.

Correspondence to: Dr. Soraya S. Smaili

E-mail: ssmaili@farm.epm.br cially when cells begin apoptotic and derive to necrotic cell death (Lemasters et al. 2002).

Apoptosis is one type of Programmed Cell Death (PCD) which regulates physiological processes involved in cell maintenance, development, tumor regression, hormone-induced atrophy, and cell-mediated immunity. Apoptosis also occurs during certain pathological states, such as ischemia-reperfusion damage, infarction, neurodegenerative diseases, viral or chemical toxicity, and can be triggered by activation of either certain death receptors on the plasma membrane or by cellular stress. Among some of the elements of the apoptotic cascade there are the activation of specific cysteine proteases (caspases); mitochondrial release of death factors, such as cytochrome $\mathrm{c}$ and SmacDiablo and finally the characteristic changes in nuclear morphology and DNA fragmentation (Green and Reed 1998). 
There are several ways to trigger apoptosis with distinct and highly complex pathways. The extrinsic pathway is triggered by the binding of death molecules to their receptors, while the intrinsic pathway is activated by various cellular insults and involves the Bcl-2 family of proteins (Youle and Strasser 2008). It has been shown that, in response to a wide variety of agents and conditions, $\mathrm{Ca}^{2+}$ signaling could also lead to apoptosis (Rong and Distelhorst 2008). Figure 1 shows the extrinsic and intrinsic signaling pathways that lead to apoptosis in mammalian cells (Orrenius et al. 2003).

\section{PROTEINS OF THE BCL-2 FAMILY AND APOPTOSIS}

Apoptosis is a natural cell elimination process involved in a great number of physiological and pathological events. This process can be regulated by members of the Bcl-2 family. Bax, a pro-apoptotic member of this family, accelerates cell death, while the pro-survival member, Bcl- $x_{\mathrm{L}}$ can antagonize the pro-apoptotic function of Bax and promote cell survival. Members of the Bcl2 family form a group of proteins that play important roles in the regulation of cell death under both physiological and pathological conditions. Proteins of this family promote either cell survival, such as Bcl-2 and Bcl- $\mathrm{x}_{\mathrm{L}}$, or cell death, such as Bax and Bid (Smaili et al. 2000, Krajewski et al. 1994). In living cells, Bax and Bid are predominantly soluble proteins (Hsu et al. 1997). Bcl-2 is associated with membranes of the organelles, including endoplasmic reticulum (ER), mitochondria, and nuclei (Krajewski et al. 1994). Bcl- $\mathrm{x}_{\mathrm{L}}$ exists in both soluble and membrane-bound forms (Hsu et al. 1997). During apoptosis, Bcl-2 remains bound to the membranes, but the cytosolic form of Bax, Bid and $\mathrm{Bcl}-\mathrm{x}_{\mathrm{L}}$ were found redistributed from the cytosol into membranes, especially mitochondrial (Hsu et al. 1997, $\mathrm{Li}$ et al. 1998). The mechanisms leading to Bax and $\mathrm{Bcl}-\mathrm{xL}$ redistribution are still not known and Bid is believed to be post-translationally cleaved by caspase- 8 leading to Bax transactivation, which is the activation followed by translocation of the protein (Li et al. 1998).

\section{BAX AS AN APOPTOTIC PROTEIN}

Bax was first identified as a Bcl-2 binding partner by immunoprecipitation (Oltvai et al. 1993). Subsequently, it was shown that overexpression of Bax can accelerate cell death in response to various apoptosis stimuli (Yang and Korsmeyer 1996). Physiologically, Bax plays an important role in neuronal development and spermatogenesis. Under pathological conditions such as cerebral and cardiac ischemia, upregulation of Bax has been detected in the afflicted area of the tissues, leading to the participation of this protein in neuronal and cardiomyocytic cell death (Krajewski et al. 1999). In certain cases of human colorectal cancer, mutations were found in the gene encoding Bax, suggesting that inactivation of Bax promotes tumorigenesis by enabling the tumor cells to be less susceptible to cell death (LeBlanc et al. 2002).

Bax, like other members of the Bcl-2 family, shares a common feature of having three conserved regions named BH (Bcl-2 homology) domains 1-3 (Zha et al. 1996). Several lines of evidence show that these domains can be important for the regulatory functions of these $\mathrm{Bcl}-2$ family proteins. In addition, Bax and other $\mathrm{Bcl}-2$ family members also possess a hydrophobic segment at their carboxyl terminal ends, which might be required for anchoring the protein to the organelles, such as ER and mitochondria (Zha et al. 1996). In healthy cells, $\mathrm{Bax}$ is predominantly a soluble monomeric protein (Hsu et al. 1997) despite the C-terminal hydrophobic segment, which is sequestered inside a hydrophobic cleft (Suzuki et al. 2000). Upon induction of apoptosis by a variety of agents, a significant fraction of Bax may translocate from the cytosol to the membrane fractions, in particular, the mitochondrial (Hsu et al. 1997, Smaili et al. 2001a). This translocation process appears to involve a conformational change in Bax leading to the exposure of its C-terminal hydrophobic domain (Nechushtan et al. 1999). The insertion of Bax into mitochondria causes the release of cytochrome $\mathrm{c}$ and loss of mitochondrial membrane potential $\left(\Delta \Psi_{\mathrm{m}}\right)$ (Goldstein et al. 2000). Cytochrome $\mathrm{c}$ activates caspase-3 leading to the proteolysis of the cell, while the loss of $\Delta \Psi_{\mathrm{m}}$ corresponds to a decrease in cellular energy production. The proapoptotic activity of Bax, however, can be counteracted by co-expression with pro-survival factors $\mathrm{Bcl}-2$ and Bcl-xL, which can block Bax translocation to mitochondria during apoptosis (Smaili et al. 2008).

Several hypotheses were proposed to explain Bax insertion into mitochondrial membranes, causing the release of cytochrome c. Three of them were mostly con- 

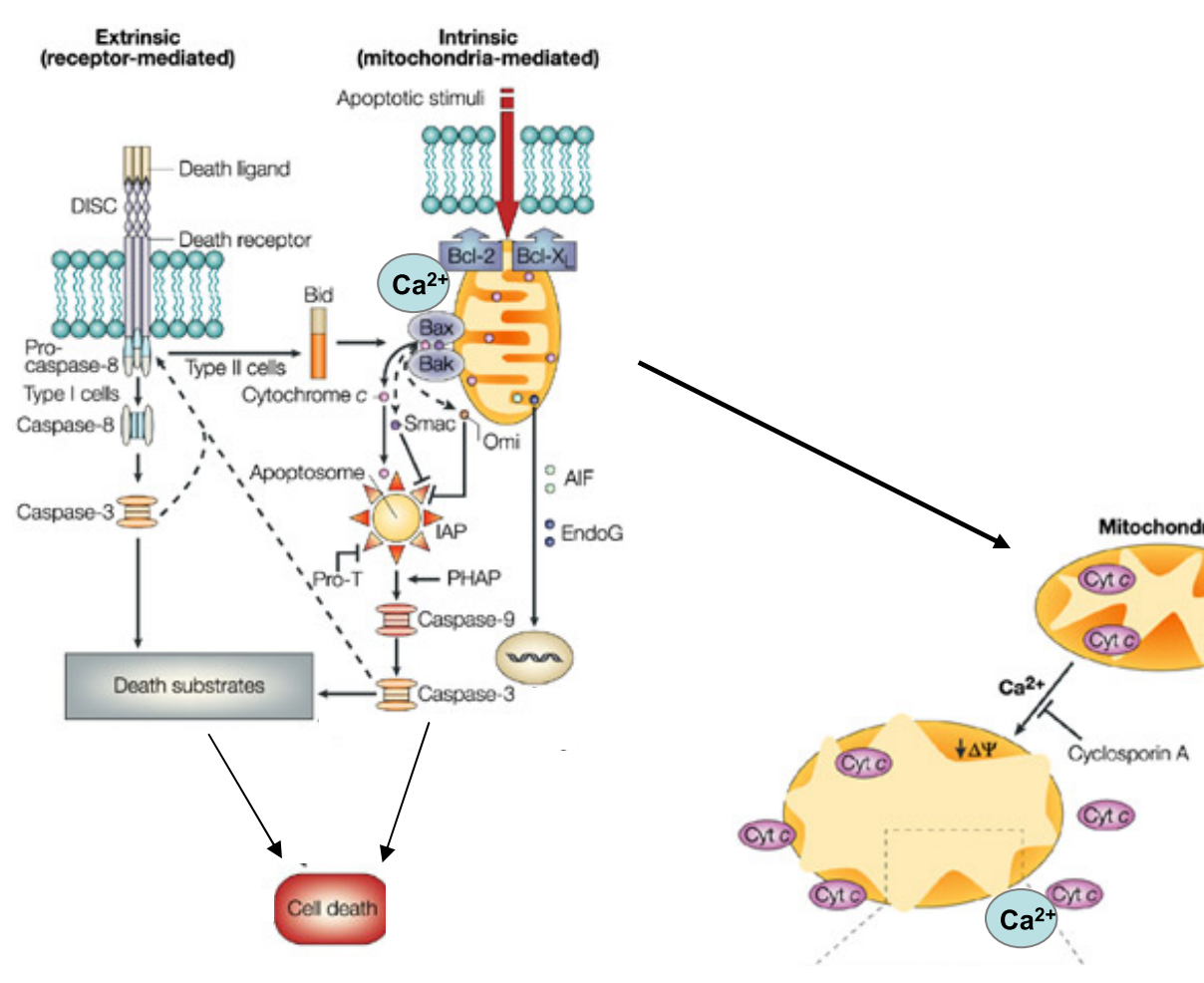

Fig. 1 - The Extrinsic and Intrinsic Pathways of Apoptosis. The extrinsic pathway is a receptor-dependent mechanism in which the activation of the death receptors leads to the formation of death-inducible signaling complex (DISC), activation of caspases 8 followed by a cascade of caspases that will execute cell death. When caspase- 8 is activated it may lead to Bid (a BH3 only pro-apoptotic protein) and intrinsic pathway activation. The intrinsic pathway is activated by the presence of apoptotic stimuli which may cause Bax translocation to mitochondria. Once in the mitochondria, Bax, together with other pro-apoptotic proteins, activates mechanisms that evoke the release of cytochrome $\mathrm{c}$ and other pro-apoptotic factors which lead to caspase-9, caspase-3 and other caspases activation that will execute cell death (Adapted from Orrenius et al. 2003 Nat Rev Mol Cell Biol 4: 552-565). Besides the release of the pro-apoptotic factors, Bax promotes $\mathrm{Ca}_{\mathrm{m}}^{2+}$ mobilization as well (Carvalho et al. 2004).

sidered: a) Bax could oligomerize and form pores which permeabilize the mitochondrial membranes (Antonsson et al. 2000, Kroemer et al. 2007); b) Bax could interact with components of the PTP, such as the ANT (Marzo et al. 1998); c) Bax could interact with other proteins that promote fission or inhibit fusion and form temporary channels (Youle and Strasser 2008). In all cases, the result is the release of cytochrome $\mathrm{c}$ and in certain circumstances this can also lead to the release of calcium to cytosol as observed in our previous results (Carvalho et al. 2004). However, the exact mechanism is still a matter of intense debate (Kroemer et al. 2007). X-ray crystallographic and solution NMR analyses of the recombinant Bcl- $\mathrm{x}_{\mathrm{L}}$ showed that it shares a high degree of structural similarity to the translocation domain of diphtheria toxin (Muchmore et al. 1996), which can insert into lipid bilayers, suggesting that Bax may form ion channels or pores (Schlesinger et al. 1997, Korsmeyer et al. 2000). Another mechanism proposed is related to the direct or indirect interaction of Bax with components of the permeability transistion pore (PTP), such as ANT or VDAC channels, which could contribute to the opening or closure of this megachannel (Kroemer et al. 2007). In addition, others have shown that Bcl-2 family proteins may modulate, together with other proteins, the fission and fusion processes, yielding the formation of transient channels throughout cytochrome $\mathrm{c}$ might be released. After the release, cytochrome $\mathrm{c}$ can interact with Apaf-1 (Zou et al. 1997) and this complex, in the presence of dATP, catalyzes the activation of caspases to induce proteolysis of the cellular constituents (Kroemer et al. 2007). 


\section{BAX AND MODULATION OF $\mathrm{Ca}^{2+}$ SIGNALING}

Recently, it has been shown that Bcl-2 proteins may regulate and be regulated by the $\mathrm{Ca}_{C}^{2+}$ levels, which influence cell death signaling (Scorrano et al. 2003, Carvalho et al. 2004). Translocation of Bax to mitochondria is associated with a release of cytochrome $\mathrm{c}$ from the mitochondrial intermembrane space (IMS) and a loss of the mitochondrial membrane potential $\left(\Delta \Psi_{\mathrm{m}}\right)$ (Smaili et al. 2001a). It is well known that mitochondria are important $\mathrm{Ca}^{2+}$ stores and they are in close relation and communication with ER (Rizzuto and Pozzan 2006). The uptake and release of $\mathrm{Ca}^{2+}$ from these organelles modulate intracellular $\mathrm{Ca}^{2+}$ signaling (Smaili and Russell 1999, Smaili et al. 2001b). In addition, $\mathrm{Ca}^{2+}$ taken up by mitochondria contributes to the activation of mitochondrial $\mathrm{Ca}^{2+}$ dehydrogenases and ATP production (Robb-Gaspers et al. 1998). Interestingly, Bax and other pro-apoptotic members of the Bcl-2 family were shown to modulate the ER and mitochondrial $\mathrm{Ca}^{2+}$ stores (Nutt et al. 2001, Pan et al. 2001). When at the ER level, Bax may deplete $\mathrm{Ca}^{2+}$ from this store and activate caspase12 (Zong et al. 2003) and, when ER $\mathrm{Ca}^{2+}$ stores are depleted, there is a reduction in Bax-induced apoptotic cell death (Scorrano et al. 2003). Since the relation between $\mathrm{Ca}^{2+}$ homeostasis, oxidative stress and apoptotic cell death is not clear, we have studied in our laboratory the role of $\mathrm{Ca}^{2+}$ and its mobilization from intracellular compartments, in the presence of apoptotic inducers, linking it to the modulation by proteins of the $\mathrm{Bcl}-2$ family, such as Bax.

We have first shown that, in Cos-7 cells transfected and overexpressing GFP-Bax, this protein is visualized soluble in the cytosol and, upon apoptotic stimuli such as staurosporine, it translocates to membranes. We have observed that when associated to mitochondria Bax induces a loss of $\Delta \Psi_{\mathrm{m}}$ (Smaili et al. 2001a). In cells co-expressing $\mathrm{Bax}$ and $\mathrm{Bcl}-\mathrm{x}_{\mathrm{L}}$, staurosporine was not able to induce neither $\Delta \Psi_{\mathrm{m}}$ loss nor Bax translocation (Smaili et al. 2008). In other cell systems, such as rat astrocytes in primary culture, recombinant protein Bax (rBax), instead of Bax overexpression, also induced a loss of $\Delta \Psi_{\mathrm{m}}$ in a concentration dependent manner (Carvalho et al. 2004). This effect was shown to be related to the inhibition of respiratory rates $(30-45 \%)$ and a partial release of cytochrome $\mathrm{c}$, with changes in the mitochondrial morphology (Carvalho et al. 2004).
The loss of $\Delta \Psi$ was associated with a permeabilization of mitochondrial membranes, which contributed to the release of $\mathrm{Ca}_{\mathrm{m}}^{2+}\left(68 \%\right.$ of the maximum $\mathrm{Ca}^{2+}$ content of the cell).

In recent studies, we have shown that the pro-apoptotic protein Bax may also modulate $\mathrm{Ca}^{2+}$ homeostasis in rat cortical astrocytes (A.P. Morales et al., unpublished data). In the absence of apoptosis induction, Bax overexpression promoted an increase in mitochondrial and $\mathrm{ER} \mathrm{Ca}^{2+}$ loads, showing a possible role for Bax apart from its pro-apoptotic action. On the other hand, we observed that drugs which promote $\mathrm{Ca}_{\mathrm{c}}^{2+}$ increase could differentially induce Bax translocation to mitochondria. The kinetics of $\mathrm{Ca}_{\mathrm{c}}^{2+}$ increase appeared to be dependent on the source of $\mathrm{Ca}^{2+}$ pools, originated from extracellular or intracellular compartments. Actually, we showed that release of $\mathrm{ER} \mathrm{Ca}^{2+}$ store evoked by different stimuli could selectively induce Bax translocation. This was corroborated by microinjection of $\mathrm{IP}_{3}$ which promoted Bax transactivation, supporting the role of ER-Ca ${ }^{2+}$ in regulating Bax and cell death activation (A.P. Morales et al., unpublished data). These findings indicate that the function of Bax and apoptosis is closely tied not only to cell death induction but also to $\mathrm{Ca}^{2+}$ homeostasis. It is interesting to note that when we have evaluated the effect of Bcl- $\mathrm{x}_{\mathrm{L}}$ on Bax-induced alterations in mitochondrial respiration and $\mathrm{Ca}^{2+}$ release, we found that $\mathrm{Bcl}-\mathrm{x}_{\mathrm{L}}$ is able to antagonize Bax-induced decrease in mitochondrial respiration and the release of $\mathrm{Ca}_{\mathrm{m}}^{2+}$ (Teles et al. 2008a). This regulation of $\mathrm{Ca}^{2+}$ by $\mathrm{Bcl}-\mathrm{x}_{\mathrm{L}}$ may represent that the modulation of $\mathrm{Ca}^{2+}$ homeostasis also contributes to a mechanism by which this protein promotes cell survival. In Figure 2 we show a schematic representation of $\mathrm{Ca}^{2+}$ signaling and the regulation by Bax.

Another interesting relation between Bax and $\mathrm{Ca}^{2+}$ stores is that, in cells microinjected with $\mathrm{rBax}$, $\mathrm{a} \mathrm{Ca}_{\mathrm{c}}^{2+}$ wave was observed and this wave was propagated from one cell to another. It is possible that the wave propagation via cell-junctions may lead to the transmission of cell death signals between cells. Our results showed that Bax induces mitochondrial alterations that affect $\mathrm{Ca}^{2+}$ homeostasis and signaling. These changes show an involvement of $\mathrm{Ca}^{2+}$ signals during apoptosis, which is probably correlated with the proapoptotic activities of Bax. 

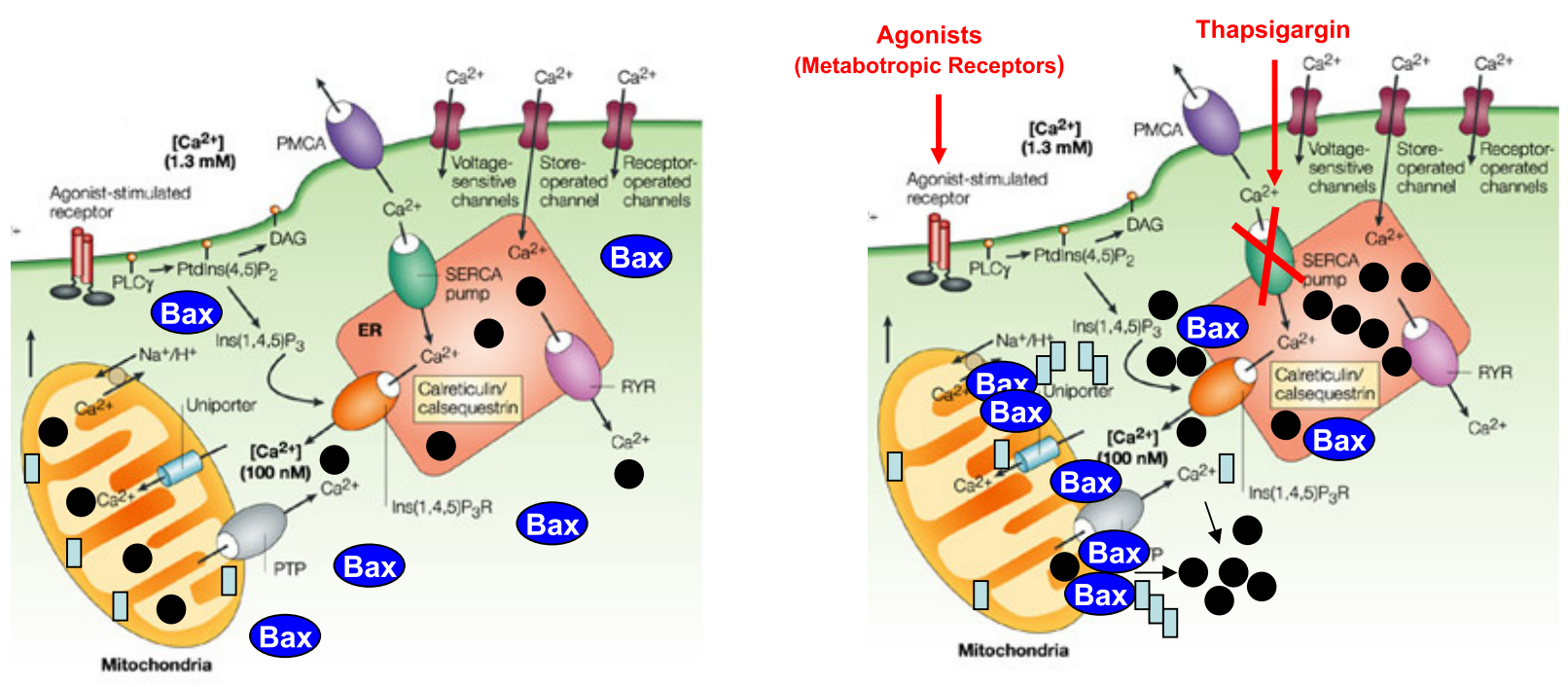

cytochrome c

Fig. $2-\mathrm{Ca}^{2+}$ homeostasis and regulation of Bax. In resting condition $\mathrm{Ca}^{2+}$ concentration is $1.3 \mathrm{mM}$ and $100 \mathrm{nM}$ at the extracellular and intracellular spaces, respectively. When metabotropic receptors are stimulated $\mathrm{Ca}_{\mathrm{c}}^{2+}$ is increased by the release of $\mathrm{Ca}^{2+}$ from intracellular stores, such as ER and mitochondria. Transient increase in $\mathrm{Ca}_{\mathrm{c}}^{2+}$ stimulates $\mathrm{Ca}^{2+}$ uptake by mitochondria found in close proximity to ER. In regular conditions, mammalian cells express low level of Bax which is soluble in the cytosol. Under stress, cells overexpress pro-apoptotic proteins such as Bax which may translocate from cytosol to the mitochondrial membranes. At the mitochondrial level, Bax may oligomerize and form pores, interact with the PTP components or interact with other proteins for fission. The results are the release of cytochrome $\mathrm{c}$ and calcium to cytosol. Stimuli that mobilize $\mathrm{Ca}^{2+}$ from intracellular stores (e.g. metabotropic receptor agonists or thapsigargin) may also induce Bax translocation and increase Bax toxicity. Once in the mitochondria, Bax leads to the permeabilization of mitochondrial membranes leading to the release of cytochrome $\mathrm{c}$ and other factors such as AIF, smacDIABLO which activate pro-caspases and down caspases that execute cell death. Bax can also release $\mathrm{Ca}_{\mathrm{m}}^{2+}$ which may amplify cell death signals and accelerate apoptosis (Adapted from Orrenius et al. $2003 \mathrm{Nat}$ Rev Mol Cell Biol 4: 552-565).

\section{CALCIUM SIGNALING AND NEURODEGENERATION}

It is well known that, during $\mathrm{Ca}_{\mathrm{c}}^{2+}$ overload, mitochondria and ER may take up $\mathrm{Ca}^{2+}$, which causes $\mathrm{Ca}_{m}^{2+}$ accumulation, change in the mitochondrial $\mathrm{pH}$, increase of the reactive oxygen species (ROS) production, decrease or complete loss of $\Delta \Psi_{\mathrm{m}}$ and opening of the PTP. Several reports showed that inhibitors of the electron transport chain, such as Malonate, 1-methyl-phenylpyridinium (MPP+) and 3-nitropropionic acid (3NP), induce cell injuries and neuronal degeneration in vitro and in vivo (Brouillet et al. 1993, Smith and Bennett 1997). The treatment with $3 \mathrm{NP}$, an irreversible inhibitor of the mitochondrial complex II succinate dehydrogenase, may cause neuronal death, leading to anatomic and neurochemical changes similar to those present in Huntington's disease (HD) patients (Beal et al. 1993, Brouillet et al. 1995).
The HD is a hereditary autosomal dominant neurodegenerative disorder caused by an expansion of CAG repeats in chromosome 4 (Gusella et al. 1983). During its development, patients with HD present motor symptoms, psychic disorders and cognitive deficits. HD, as many neurodegenerative processes, is associated with changes in $\mathrm{Ca}^{2+}$ homeostasis and ROS production. Because mitochondria are important for $\mathrm{Ca}^{2+}$ homeostasis and signaling, and are also involved in apoptotic cell death, there is a special interest in understanding the relation of $\mathrm{Ca}^{2+}$ and cell death signaling with the neurodegenerative processes.

In our studies we have also investigated cellular mechanisms related to mitochondrial dysfunctions induced by 3 NP. In addition, we have looked to $\mathrm{Ca}^{2+}$ homeostasis in the brain slices from HD transgenic mice, a method developed in our laboratory (Smaili et al. 2008). These animals were also used to investigate 
apoptosis and its relation with the levels of $b c l-2$ and bax, genes that encode the anti-apoptotic protein Bcl2 and the pro-apoptotic protein Bax, respectively. We showed that $3 \mathrm{NP}$ is able to release $\mathrm{Ca}_{\mathrm{m}}^{2+}$ in mice astrocytes and, in the presence of PTP inhibitors and antioxidants, this effect was inhibited. Thus, inhibition of the complex II by $3 \mathrm{NP}$ is associated with $\mathrm{Ca}_{\mathrm{m}}^{2+}$ release, increase in ROS production and PTP opening. The 3NP also induced apoptosis in these cells (Rosenstock et al. 2004). In transgenic mice for HD we have observed that there is a sustained and significant increase in $\mathrm{Ca}_{\mathrm{c}}^{2+}$ after a stimulation of brain slices with glutamate (Smaili et al. 2008), which might be related to the increased levels of $\mathrm{Ca}^{2+}$ in intracellular stores and with the inability of mitochondria to uptake high levels of the ion present in the cytosol. We have also investigated the participation of gene expression of bax and $b c l-2$ in tissues from R6/1 transgenic (TGN) mice with different ages (3, 6 and 9 months). The mRNAs expression were investigated and related to apoptotic cells measured by TUNEL. Results showed a significantly progressive (from 6 to 9-monthold) increase in bax mRNA levels in the cortex of TGN when compared to control mice. There was a decrease in the $b c l-2 / b a x$ ratio which was associated with the increase in the number of apoptotic nuclei. It is possible that the elevation of bax is related to cellular changes that contribute to neurodegeneration and support the idea that, in different cell models, the alterations in $\mathrm{Ca}_{\mathrm{c}}^{2+}$ handling and the levels of the $\mathrm{Ca}^{2+}$ stores may modulate important steps of the cell death signaling which can contribute to cellular degeneration and to apoptotic cell death induction (Teles et al. 2008b).

\section{CALCIUM STORES, CELL DEATH AND AGING}

Aging is a multi-faceted process associated with several functional and structural deficits, and the brain is one of the most affected systems by chronic and degenerative diseases. Among them, Alzheimer's and Parkinson's diseases are the most prevalent in the world and cause the most severely impairments of actions. Therefore, it is necessary to investigate the age-related risk factors and the possible mechanisms involved in brain damage and the future perspectives for protection and therapeutics. In addition, it is also known that, in neurodegenerative disorders, there are alterations in $\mathrm{Ca}^{2+}$ homeostasis which contribute to cell death. In our pre- vious work, we have shown that, in different tissues from senescent rats, there is an increase in $\mathrm{Ca}^{2+}$ content in the intracellular stores, such as the ER and mitochondria (Lopes et al. 2004, 2006). These data can be corroborated by a decrease in $\mathrm{Ca}^{2+}$ buffering capacity, as well as an increase in apoptotic cell death in different smooth muscle tissues (Lopes et al. 2006, 2007). Recently, we have investigated the alterations in $\mathrm{Ca}^{2+}$ signaling and the possible involvement with mitochondrial dysfunction and activation of pro-apoptotic factors. We studied some phenomena concerning the triad $\mathrm{Ca}^{2+}$-mitochondria-ROS (Toescu and Verkhratsky 2007) and apoptosis in striatum of aged rats. Our results showed that glutamate evoked a $\mathrm{Ca}^{2+}$ rise which was greater in slices from aged animals. The evaluation of the intracellular $\mathrm{Ca}^{2+}$ contents of the ER and mitochondria were increased in this group. Additionally, there was a reduction in the $\Delta \Psi m$, an increase in basal ROS levels and an inhibition of the complex I, which could be associated with an increased vulnerability (R.P. Ureshino et al., unpublished data). As investigated for HD neurodegenerative process, we have also analyzed the elements of apoptotic pathway such as Bax and Bcl-2 gene and protein expression. The results showed an increase in bax transcript and a decrease in Bcl-2 protein which might be associated with the increase in apoptosis observed in senescent rats. Altogether, these results show that in aging, as well as in neurodegeneration, there are alterations in $\mathrm{Ca}^{2+}$ handling that may affect the bioenergetic and mitochondrial functions and may contribute to apoptotic induction and cell death process (R.P. Ureshino et al., unpublished data).

\section{FUTURE PERSPECTIVES}

In the past recent years, several lines of evidence have shown that calcium signaling is involved in apoptotic cell death caused by certain stimuli. It is also clear that members of the Bcl-2 family of proteins may regulate or be regulated by the levels of calcium at the intracellular stores. Thus, the communication between the two main organelles that accumulate calcium, ER and mitochondria, may determine and modulate the apoptotic pathways as well. However, several aspects of this relationship between calcium and cell death signaling are still unknown and should be a source of investigation by many researchers. Since in many diseases the levels of 
anti- and pro-apoptotic proteins are altered and these proteins modulate and are modulated by calcium signals, it will be necessary to further elucidate the exact roles of Bcl-2 family and calcium homeostasis in cell death.

\section{ACKNOWLEDGMENTS}

This project was supported by grants from Fundação do Amparo à Pesquisa do Estado de São Paulo (FAPESP), by Conselho Nacional de Desenvolvimento Científico e Tecnológico (CNPq) and Coordenação Aperfeiçoamento de Pessoal do Ensino Superior (CAPES) fellowships.

\section{RESUMO}

Aumentos transientes no cálcio citosólico $\left(\mathrm{Ca}_{\mathrm{c}}^{2+}\right)$ e mitocondrial $\left(\mathrm{Ca}_{\mathrm{m}}^{2+}\right)$ são elementos essenciais no controle de muitos processos fisiológicos. No entanto, aumentos sustentados do $\mathrm{Ca}_{\mathrm{c}}^{2+}$ e do $\mathrm{Ca}_{\mathrm{m}}^{2+}$ podem contribuir para o estresse oxidativo e a morte celular. Muitos eventos estão relacionados ao aumento no $\mathrm{Ca}_{\mathrm{c}}^{2+}$, incluindo a regulação e ativação de várias enzimas dependentes de $\mathrm{Ca}^{2+}$ como as fosfolipases, proteases e nucleases. A mitocôndria e o retículo endoplasmático têm um papel central na manutenção da homeostase intracellular de $\mathrm{Ca}_{\mathrm{c}}^{2+} \mathrm{e}$ na regulação da morte celular. Várias evidências mostraram que, na presença de certos estímulos apoptóticos, a ativação dos processos mitocondriais pode promover a liberação de citocromo c, seguida da ativação de caspases, fragmentação nuclear e morte celular por apoptose. O objetivo desta revisão é mostrar como aumentos na sinalização de $\mathrm{Ca}^{2+}$ podem estar relacionados aos eventos de indução da morte celular apoptótica. Além disso, evidenciar como a homeostase de $\mathrm{Ca}^{2+}$ pode ser importante e está envolvida nos mecanismos presentes nos processos de neurodegeneração e envelhecimento.

Palavras-chave: cálcio, apoptose, Bax, mitocôndrias, retículo endoplasmático, neurodegeneração e envelhecimento.

\section{REFERENCES}

Antonsson B, Montessuit S, LAuper S, Eskes R And MARTINOU JC. 2000. Bax oligomerization is required for channel-forming activity in liposomes and to trigger cytochrome c release from mitochondria. Biochem J 345: 271-278.

Beal mF, Brouillet E, Jenkins BG, Ferrante RJ, Kowall NW, Miller JM, Sotorey E, Srivastava R, Rosen B And Hyman BT. 1993. Neurochemical and histologic characterization of striatal excitotoxic le- sion produced by the mitochondrial toxin 3-nitropropionic acid. J Neurochem 13: 4181-4192.

Brouillet E, Jenkins BG, Hyman BT, Ferrante RJ, Kowall NW, Srivastava R, Roy DS, Rosen BR AND BEAL MF. 1993. Agedependent vulnerability of the striatum to the mitochondrial toxin 3-nitropropioni acid. J Neurochem 60: 356-359.

Brouillet e, Hantraye P, Ferrante RJ, Dolan R, Leroy-Willig A, Kowall NW and Beal MF. 1995. Chronic mitochondrial energy impairment produces selective striatal degeneration and abnormal choreiform movements in primates. Proc Natl Acad Sci USA 92: 71057109.

Carvalho ACP, Sharpe J, Rosenstock RR, Teles AV, Youle RJ AND SMAILi SS. 2004. Bax affects intracellular $\mathrm{Ca}^{2+}$ stores and induces $\mathrm{Ca}^{2+}$ wave propagation. Cell Death Diff 11: 1265-1276.

Goldstein JC, Waterhouse NJ, Juin P, EVAN GI AND GREEN DR. 2000. The coordinate release of cytochrome c during apoptosis is rapid, complete and kinetically invariant. Nat Cell Biol 2: 156-162.

Green DR And ReED JC. 1998. Mitochondria and Apoptosis. Science 281: 1309-1311.

GUSELla JF ET AL. 1983. A polymorphic DNA marker genetically linked to Huntington's disease. Nature 306: 234-238.

HSu Y-T, Wolter K And Youle RJ. 1997. Cytosol-tomembrane redistribution of $\mathrm{Bax}$ and $\mathrm{Bcl}-\mathrm{X}(\mathrm{L})$ during apoptosis. Proc Natl Acad Sci USA 94: 3668-72.

Korsmeyer SJ, Wei MC, SAito M, Weiler S, OH KJ AND SCHELESINGER PH. 2000. Pro-apoptotic cascade activates BID, which oligomerizes BAK or BAX into pores that result in the release of cytochrome c. Cell Death Diff 7: 1166-1173.

Krajewski S, Krajewski M, Shabaik A, Miyashita, WANG HG AND REED JC. 1994. Immunohistochemical determination of in vivo distribution of Bax, a dominant inhibitor of Bcl-2. Am J Pathol 145: 1326-1336.

KRAJEWSKI S ET AL. 1999. Release of caspase-9 from mitochondria during neuronal apoptosis and cerebral ischemia. Proc Natl Acad Sci USA 96: 5752-5757.

Kroemer K, Galluzzi L and Brenner C. 2007. Mitochondrial Membrane Permeabilization in Cell Death. Physiol Rev 87: 99-163.

LeBlanc H, Lawrence D, Varfolomeev E, Totpal K, Morlan J, Schow P, Fong S, Schwall R, SiniCROPI D AND AshKenAzI A. 2002. Tumor-cell resis- 
tance to death receptor-induced apoptosis through mutational inactivation of the proapoptotic Bcl-2 homolog Bax. Nat Med 8: 274-281.

Lemasters JJ, Qian T, He L, Kim JS, Elmore SP, CASCIO WE AND BRENNER DA. 2002. Role of mitochondrial inner membrane permeabilization in necrotic cell death, apoptosis and autophagy. Antioxid Redox Signal 4: 769-781.

LI H, ZHU H, XU CJ AND YUAN J. 1998. Cleavage of BID by caspase 8 mediates the mitochondrial damage in the Fas pathway of apoptosis. Cell 94: 491-501.

LOPES GS, MORA OA, CERri P, FARIA FP, JURKIEWICZ NH, JurkiewiCz A ANd SMAILi SS. 2004. Mitochondrial alterations and apoptosis in smooth muscle from age rats. Biochim Biophys Acta 1658: 187-194.

Lopes GS, Ferreira AT, Oshiro ME, Vladimirova I, Jurkiewicz NH, Jurkiewicz A AND Smaili SS. 2006. Aging-related changes of intracellular $\mathrm{Ca}^{2+}$ stores and contractile response of intestinal smooth muscle. Exp Gerontol 41: 55-62.

Lopes GS, Smaili SS, Neto AC, Vladimirova I, JURKIEWICZ A AND JURKIEWICZ NH. 2007. Aginginduced decrease of cholinergic response and calcium sensitivity on rat jejunum contractions. J Gerontol A Biol Sci Med Sci 62: 264-270.

MARZO I ET AL. 1998. Bax and adenine nucleotide translocator cooperate in the mitochondrial control of apoptosis. Science 281: 2027-2031.

MUCHMORE SW ET AL. 1996. X-ray and NMR structure of human Bcl-xL, an inhibitor of programmed cell death. Nature 381: 335-341.

Nechushtan A, Smith CL, Hsu YT and Youle RJ. 1999. Conformation of the Bax C-terminus regulates subcellular location and cell death. EMBO J 18: 2330-2341.

Nutt LK, Pataer A, Pahler J, Fang B, Roth J, McConkey DJ AND Swisher SG. 2001. Bax and Bak promote apoptosis by modulating endoplasmic reticular and mitochondrial $\mathrm{Ca}^{2+}$ stores. J Biol Chem 277: 20301-20308.

Oltvai ZN, Milliman CL and Korsmeyer SJ. 1993. Bcl-2 heterodimerizes in vivo with a conserved homolog, Bax, that accelerates programmed cell death. Cell 74: 609-619.

ORReniUs S, Zivotovski B AND Nicotera P. 2003. Regulation of Cell Death: The Calcium-Apoptosis link. Nat Rev Mol Cell Biol 552: 552-565.
Pan Z, Bhat MB, Nieminen AL and Ma J. 2001. Synergistic movements of $\mathrm{Ca}^{2+}$ and Bax in cells undergoing apoptosis. J Biol Chem 276: 32257-32263.

Rizzuto R And Pozzan T. 2006. Microdomains of intracellular $\mathrm{Ca}^{2+}$ : molecular determinants and functional consequences. Physiol Rev 86: 369-408.

Robb-Gaspers LD, Burnett P, Rutter GA, Denton RA, Rizzuto R AND Thomas AP. 1998. Integrating cytosolic calcium signals into mitochondrial metabolic responses. EMBO J 17: 4987-5000.

RONG Y AND DisTELHORST CW. 2008. Bcl-2 protein family members: versatile regulators of calcium signaling in cell survival and apoptosis. Annu Rev Physiol 70: 73-91.

Rosenstock TR, Carvalho ACP, Jurkiewicz A, Frussa-Filho R AND SMaIli SS. 2004. Mitochondrial calcium, oxidative stress and apoptosis in a neurodegenerative disease model induced by 3-nitropropionic acid. J Neurochem 88: 1220-1228.

Schlesinger PH, Gross A, Yin XM, YAmamoto K, SAITO M, WAKSMAN G AND KorSMEYER SJ. 1997. Comparison of the ion channel characteristics of proapoptotic BAX and antiapoptotic BCL-2. Proc Natl Acad Sci USA 94: 11357-113562.

Scorrano L, OAKes SA, Opferman JT, Cheng EH, Sorcinelli MD, POZZAN T AND KorsmeYer SJ. 2003. BAX and BAK regulation of endoplasmic reticulum $\mathrm{Ca}^{2+}$ : a control point for apoptosis. Science 300 : 135-139.

SMAILI SS AND RUSSELL JT. 1999. Permeability transition pore regulates both mitochondrial membrane potential and agonist-evoked $\mathrm{Ca}^{2+}$ signals in oligodendrocytes progenitors. Cell Calcium 26: 121-130.

Smaili SS, YT, Youle RJ And Russell JT. 2000. Mitochondria in $\mathrm{Ca}^{2+}$ Signaling and Apoptosis. J Bioenerg Biomembr 32: 35-46.

Smaili SS, Hsu YT, SANDER K, Russell JT AND Youle RJ. 2001a. Bax translocation to mitochondria subsequent to a rapid loss of mitochondrial membrane potential. Cell Death Differ 8: 909-920.

Smaili SS, Stelatto KA, Burnet P, Thomas AP And GASPERS LD. 2001b. Cyclosporin A inhibits inositol 1,4,5-trisphosphate-dependent $\mathrm{Ca}^{2+}$ signals by enhancing $\mathrm{Ca}^{2+}$ uptake into the endoplasmic reticulum and mitochondria. J Biol Chem 276: 23329-23340.

SMAili SS, Rosenstock TR AND HsU Y-T. 2008. Evaluation of Some Cell Death Features by Real-Time, RealSpace Microscopy. Methods Enzymol 442: 27-50. 
SMith TS AND BENNETt JP JR. 1997. Mitochondrial toxins in neurodegenerative diseases: In vivo brain hydroxyl radical production during systemic MPTP treatment or following microdialysis infusion of methylpyridinium or azide ions. Brain Res 765: 183-186.

Suzuki M, Youle RJ AND TJANDRA N. 2000. Structure of Bax: coregulation of dimer formation and intracellular localization. Cell 103: 645-654.

Teles AV, UReshino RP, DorTa DJ, Lopes GS, Hsu YT AND SMAILI SS. 2008a. Bcl-x(L) inhibits Bax-induced alterations in mitochondrial respiration and calcium release. Neurosci Lett 442: 96-99.

Teles AV, Rosenstock TR, OKuno CS, Lopes GS, BERTONCINI CR AND SMAILI SS. 2008b. Increase in bax expression and apoptosis are associated in Huntington's disease progression. Neurosci Lett 438: 59-63.

Toescu EC And Verkhratsky A. 2007. Role of calcium in normal aging and neurodegeneration. Aging Cell 6: 267-273.
YANG E AND KORSMEYER SJ. 1996. Molecular apoptosis: a discourse on the Bcl-2 family and cell death. Blood 88 : 386-401.

Youle RJ AND STRASSER A. 2008. The BCL-2 protein family: opposing activities that mediate cell death. Nat Rev Mol Cell Biol 9: 47-59.

Zha H, Kisk HA, YAFFe MP, Mahajan N, HeRman B AND REED JC. 1996. Structure-function comparisons of the proapoptotic protein Bax in yeast and mammalian cells. Mol Cell Biol 16: 6494-6508.

Zong WX, Li C, Hatzivassiliou G, Lindsten T, Yu QC, YUAN J AND ThOMPson CB. 2003. Bax and Bak can localize to the endoplasmic reticulum to initiate apoptosis. J Cell Biol 162: 59-69.

Zou H, Henzel WJ, LiU X, Lutschg A and Wang X. 1997. Apaf-1, a human protein homologous to C. elegans CED-4, participates in cytochrome c-dependent activation of caspase-3. Cell 90: 405-413. 